\title{
The Use of Fine Blast Furnace Slag in Improvement of Properties of Concrete
}

\author{
Hamadallah Al-Baijat, Mohmd Sarireh* \\ Department of Civil Engineering, Faculty of Engineering, Tafila Technical University, Tafila, Jordan \\ Email:albaijath@yahoo.com, *m.sarireh@gmail.com
}

How to cite this paper: Al-Baijat, $\mathrm{H}$. and Sarireh, M. (2019) The Use of Fine Blast Furnace Slag in Improvement of Properties of Concrete. Open Journal of Civil Engineering, 9, 95-105.

https://doi.org/10.4236/ojce.2019.92007

Received: March 1, 2019

Accepted: April 27, 2019

Published: April 30, 2019

Copyright $\odot 2019$ by author(s) and Scientific Research Publishing Inc. This work is licensed under the Creative Commons Attribution International License (CC BY 4.0).

http://creativecommons.org/licenses/by/4.0/

\section{c) (i) Open Access}

\begin{abstract}
Concrete properties can be improved using Fine Blast Furnace Slag (BFS). The latter was used to replace cement in concrete at $10 \%, 15 \%, 20 \%, 25 \%$, and $30 \%$ proportions and properties of both fresh and hardened concrete improved. Best workability (evaluated by slump and Table tests) was recorded at $30 \%$ of BFS addition. VEBE-time, an indication of workability of concrete, decreased to its lowest value (about 4 seconds at 30\% BFS) and compaction factor attained its maximum value of $99 \%$ at BFS $25 \%$. For density and unit weight, $30 \%$ of fine BFS in concrete mix resulted in maximum density of 2180 $\mathrm{kg} / \mathrm{m}^{3}$ for fresh concrete, and $2430 \mathrm{~kg} / \mathrm{m}^{3}$ for hardened concrete. Unit weight of concrete achieved a maximum of $23.9 \mathrm{kN} / \mathrm{m}^{3}$ at $30 \%$ BFS has achieved specified strength at $1^{\text {st }}$ week and 28 days, also the late strength is high at 56 and 84 days. Bond and flexure loads come high of BFS use. The data of compressive, bond, and flexural strengths are highly related. Results of research are useful and may be applied using fine BFS to improve the properties of concrete materials.
\end{abstract}

\section{Keywords}

Bond Strength, Compressive Strength, Density of Concrete, Unit Weight of Concrete, Workability, Blast Furnace Slag

\section{Introduction}

The use of fine blast furnace slag (BFS) is widely applicable to increase the strength of concrete, especially the late age strength. However, there is an optimum point for the BFS added. Above that point, increasing BFS amount will not remarkably increase concrete strength. The use of BFS is useful in improving the durability, and reducing porosity (through the increasing of the interface be- 
tween aggregate grains). The analysis of the blending process between the new admixture (BFS) and the basic binder (Portland cement) requires finding the optimum point of mixing that indicates when to stop the addition of the furnace slag admixture. Other admixtures (such as silica fume, fly ash, slag, natural pozzolana) may be required at quantities different from that of the furnace slag [1]. The addition of furnace slag to the concrete mix as a replacement to the blended cement is an advanced method in improving the strength of concrete and enhancing its behavior. Many of the parameters of the concrete mix will improve and practically are changed effectively especially the water to cement ratio, slag-cement replacement ratio, and the development of concrete parameters through the curing of concrete. However, the use of high percentages of ground furnace slag may adversely affect the concrete early strength (such as 1-day strength) when furnace slag is mixed at $50 \%$. Consequently, a higher ratio of mixed furnace slag (60\% and higher) will incorporate low compressive strength beyond 180-day age of concrete compared to the control samples of concrete made using Portland cement [2].

Economically and ecologically, the use of furnace slag in concrete mixes is important to reduce the cumulative and increasing piles of the by-product materials of slag [3]. Also, it is economically effective to use a cheap by-product material in replacement of an expensive material such as cement in the concrete mix. It is energy saving to use a recycled harmful material to the environment and the high cost for the traditional damping actions and conditions, and it is a good method to improve conservative concrete parameters and strengths [4].

It is important to define the optimum ratio for mixing the furnace slag with the Portland cement, and when it will be possible to continue on increasing increments and high ratios of the supplementary materials for the cement in the concrete mix. To do that, it's required to build a model for the cement hydration and the supplementary reaction in the concrete mix [5]. Also, it's required to study how the workability parameters as mixing and replacement in fresh concrete are affected by the slag ratio added. Performance of the hardened concrete properties represented by its density and unit weight, compressive strength (at early and later ages) must also be evaluated [6]. So, it may be useful to build a mathematical model connecting concrete parameters (density, unit weight, and compressive strength) as functions on the ratio of supplementary material (furnace slag and cement) and these parameters can be predicted in the proposed system. Furnace slag will be incorporated into the concrete to make changes in hydration chemistry by first chemical reaction of amorphous phase of slag, and second the influence of furnace slag on the hydration of cement. This is strongly due to the amount of capillary water and dilution. The temperature of curing and the percentage of mixing slag are other important factors in the hydration of cement and the reaction between furnace slag and cement in the concrete mix. In addition to the water/cement ratio in the mix and the age of concrete they affect the hydration level and so the concrete compressive strength [7] [8]. 
It was reported that several industrial by-products such as silica fumes, different types of slag and fly ash have been used successfully as supplementary cementations material (cement material) in the concrete mixes to obtain a sustainable environmental solution for some of the by-products such as furnace slag from the industrial processes. Supply of these materials requires low cost, energy and time as they are mostly produced as industrial wastes or by-products. Slag is a by-product from steel industries that and is always available in considerable amounts. The furnace slag is naturally separated from iron then collected and cooled through the use of huge amount of cooling water. The liquid furnace slag is then transformed into small sized particles of amorphous structure. Following by consequent drying process, the particles are ground to the desired fineness that enables the material of having the properties of the cementacious agent such as cement in concrete mix. The study was conducted at different types and resources of furnace slag that were collected from different industrial sites. Samples were analyzed physically and chemically, then specimens of 4 -inches cubes were casted at percentages of furnace slag at $0 \%, 20 \%, 30 \%$, and $40 \%$. The samples were tested for the concrete compressive strength at different ages including 7-day, 28-day, and 60-day. The study shows that the compressive strength is reduced for high percentages of furnace slag, and is reduced also for longer ages of curing of concrete [9].

The current research aims to introduce the use of blast furnace slag as a replacing agent of classical Portland cement in Jordan. One reason is to get high quality (fresh and hardened) concretes. The slag is used for this purpose because it has binding properties (similar to those of hydraulic cements) and its wide availability. In addition to that, increasing use of this recycled by-product in construction in various structures (through the replacement of cement by the furnace slag) will benefit the society by minimizing pollution and lowering the cost of concrete mixes (as slag is much cheaper than classical cement).

\section{Experimental Work and Preparation}

All the materials necessary for preparing concrete mixes including: fine sand, medium aggregate, coarse aggregate, cement and ground blast furnace slag were prepared to produce mixes $20 \mathrm{MPa}$ compressive strengths. The concrete mix was prepared at the percentages $0 \%, 10 \%, 15 \%, 20 \%, 25 \%, 30 \%$, and $35 \%$ of cement as furnace slag. All the concrete mixes were tested at fresh stage for compaction factor [10], slump value [11], workability by flow table [12], and VEBE Time [13]. Also, specimens of concrete $15 \mathrm{~cm}$ cubes were prepared [14] at each percentage of furnace slag and all specimens were weighed to calculate density [15] and unit weight of concrete [16], and compressive strength [17].

ASTM C138/C138M-17a [18], Standard Test Method for Density (Unit Weight), Yield, and Air Content (Gravimetric) of Concrete, compressive strength [19] and bond stress were tested also at 7-day, 14-day, and 28-day. Also a flexural stress evaluated at the same ages of concrete using prism beams of $(50 \mathrm{~cm} \times 10$ 
$\mathrm{cm} \times 10 \mathrm{~cm}$ ) according to the method of testing.

\section{Results and Discussions}

The results of current research on fresh and hardened concrete are shown below.

\subsection{Fresh Concrete}

\subsubsection{Workability}

Figure 1 shows how the workability of BFS concrete mixes changes with increasing the slag ratio. The workability of 0 -slag is high (about $26 \mathrm{~cm}$ ). With increasing the slag \%, the workability decreases and reaches a minimum value at $25 \%$ slag, then increases again to reach a maximum corresponding to $30 \%$ slag addition. It is not known why only after $25 \%$ slag addition workability starts to increase. It is not known also whether the undulatory shape of the relationship shown in Figure 1 between slag content and workability will continue or not, if the slag content increased gradually to reach $100 \%$.

Figure 2 shows the slump value (in $\mathrm{cm}$ ) for concrete using furnace slag. The

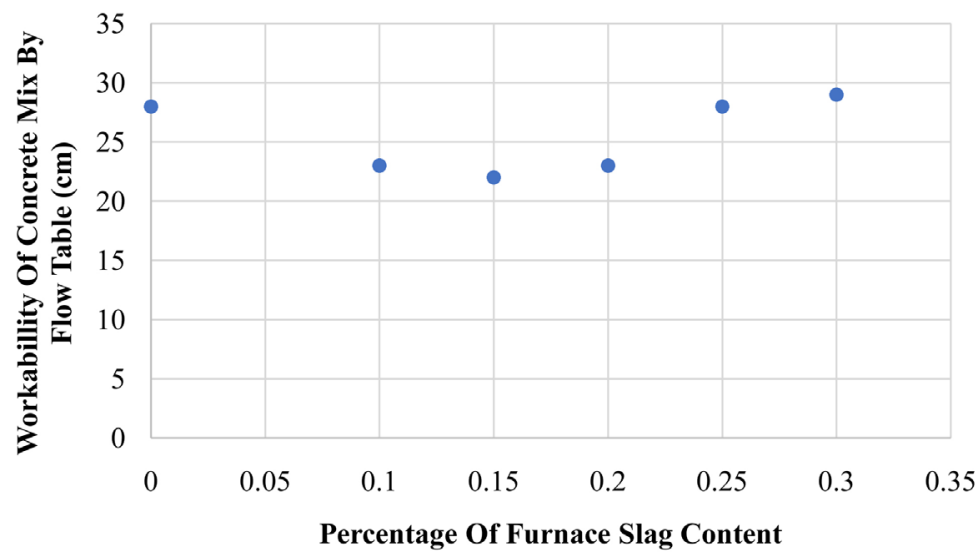

Figure 1. Workability of BFS concrete by flow table.

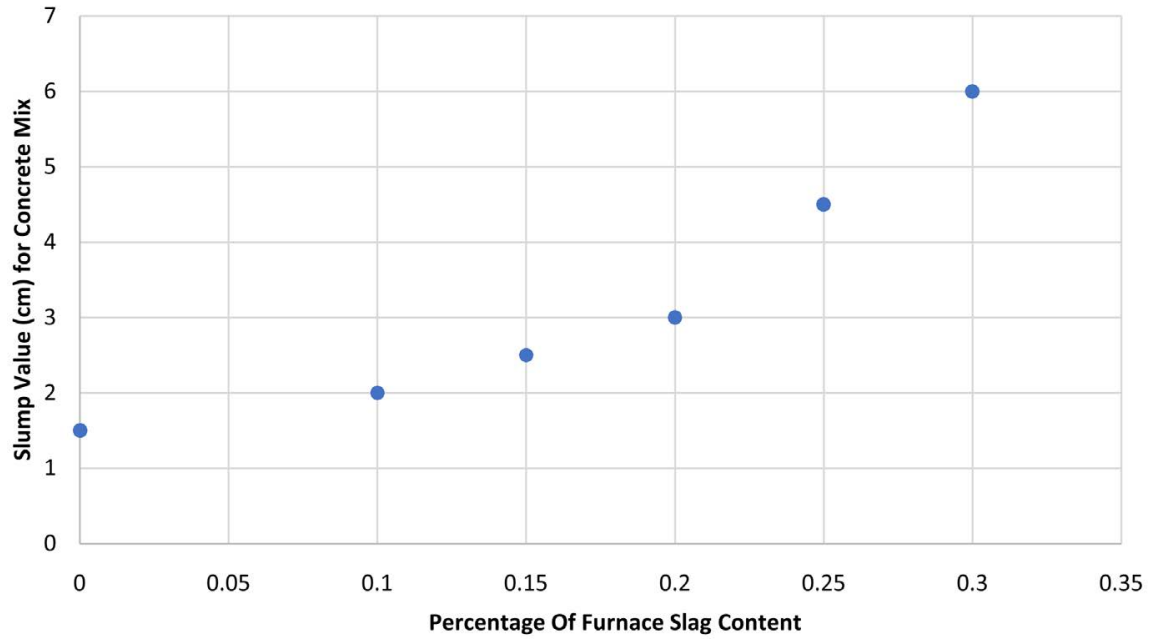

Figure 2. Slump value for concrete mix using BFS. 
0 -slag concrete has 7-cm slump, and it is clear that the addition of slag increases the value of slump up to $6 \mathrm{~cm}$. Also, it is obvious by taking slopes for the relation that $21 \%$ of slag is optimum for the slump.

Figure 3 shows the compaction factor for concrete using furnace slag. It is obvious from Figure 3 that 25\% of slag added to the concrete mix gives $98 \%$ compaction factor.

Figure 4 shows that VEBE time decreases with the increasing the percentage of slag as the workability increase, that agrees with the relations of workability and slump with the addition of slag to the mix.

\subsubsection{Density of Concrete}

The density of fresh concrete is an important property in calculating the weight and load of concrete on forms and bridges. So, in current study the compacted and non compacted densities of concrete were measured and calculated. Compaction factor was also calculated by dividing the non compacted density by the compacted density. Figure 5 presents the non compacted and compacted densities of concrete and their variation due to the use of BFS in concrete mix.

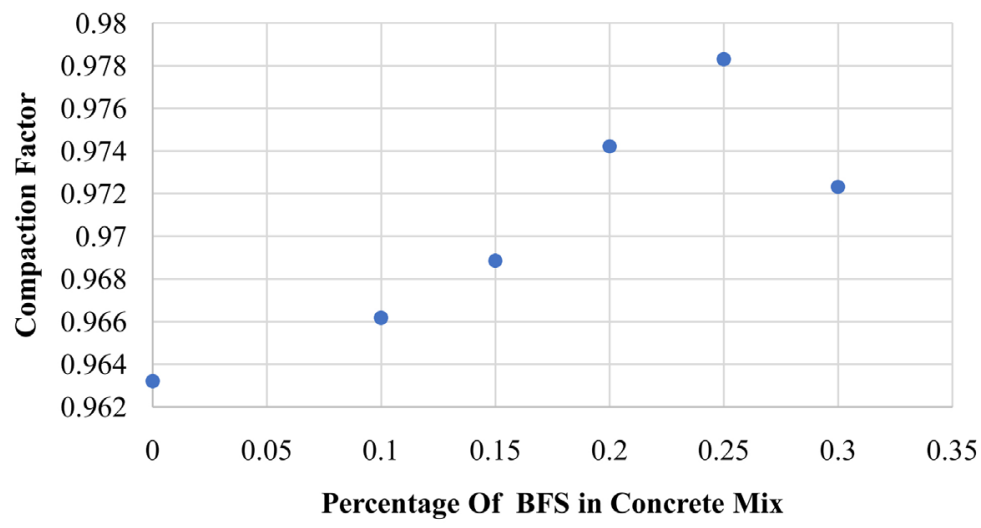

Figure 3. Compaction factor of concrete mix by BFS.

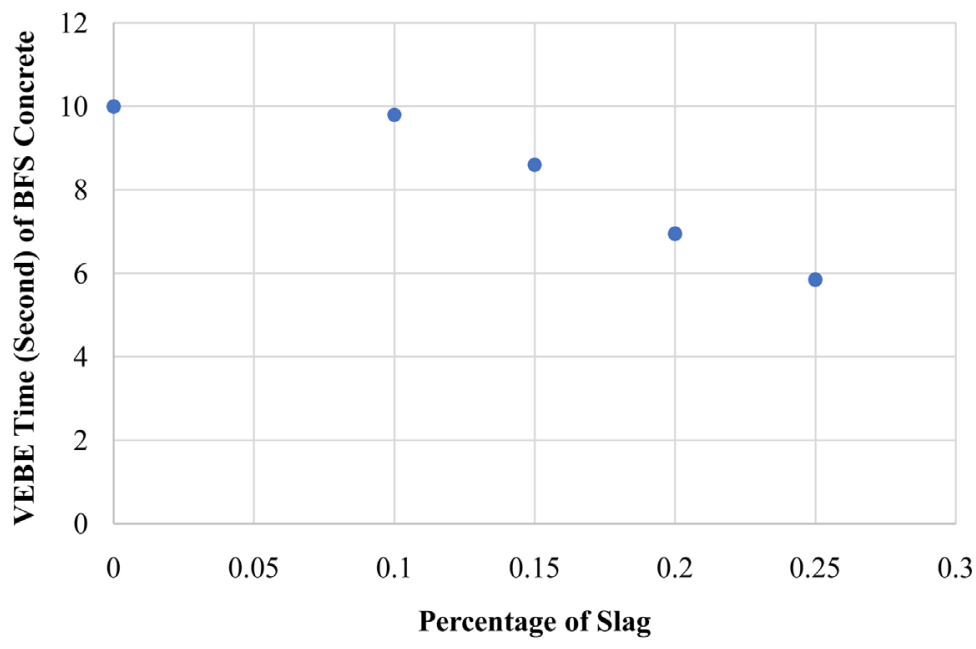

Figure 4. VEBE time (seconds) for concrete mix using BFS. 


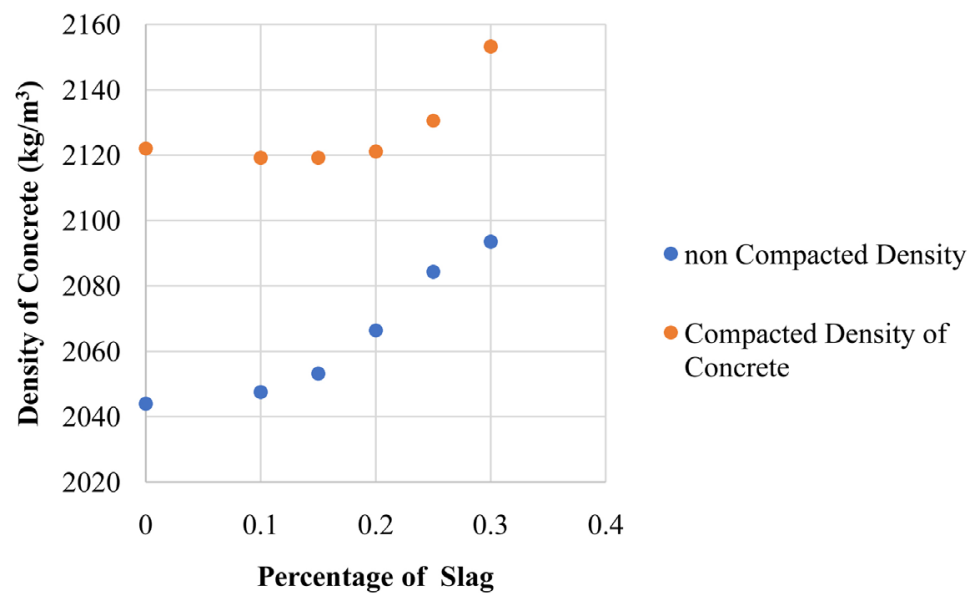

Figure 5. Compacted and non compacted densities of BFS concrete.

Obviously, compacted concrete has higher values of density. But, the increase of density in non compacted concrete is opponent to the decrease in density of compacted concrete. This is due to the density of BFS compared to the density of compacted and non compacted densities of concrete.

\subsection{The Properties of Hardened Concrete}

The hardened properties of concrete including its density, unit weight, and compressive strength were used to study the effect of the use of BFS on concrete mixes.

Figure 6 presents how the density of hard concrete changes with both BFS\% and time. The density of hard concrete increases with increasing of BFS percentage, and of all slag ages the $30 \%$ of BFS gives the highest value for hardened density.

Figure 7 presents the unit weight of hardened concrete with the use of BFS on time. Also, $30 \%$ of BFS gets the higher value of unit weight of $23.85 \mathrm{kN} / \mathrm{m}^{3}$ because of the addition of BFS.

Figure 8 presents the compressive strength of concrete using BFS. And the $30 \%$ of BFS increases the strength on all stages especially at 77 days the last stage of testing concrete compressive strength that gets $34 \mathrm{kN} / \mathrm{m}^{3}$.

Figure 9 presents the bond load of concrete using the BFS. The maximum load bond is achieved at 77 days of $85 \mathrm{kN}$.

Figure 10 presents flexural strength of concrete using BFS. The load of flexure of $24 \mathrm{kN}$ at 77 days is the highest using $30 \%$ of BFS.

Figure 11 presents the relation between compressive strength and bond load of BFS concrete. It seems that the relation is high between these variables and the value of compressive strength can explain the bond load depending on the relation for all percentages.

Figure 12 presents the relation between the compressive strength and the flexural load of BFS concrete. Also, the relation is strong and positive, and each variable can predict the other. 


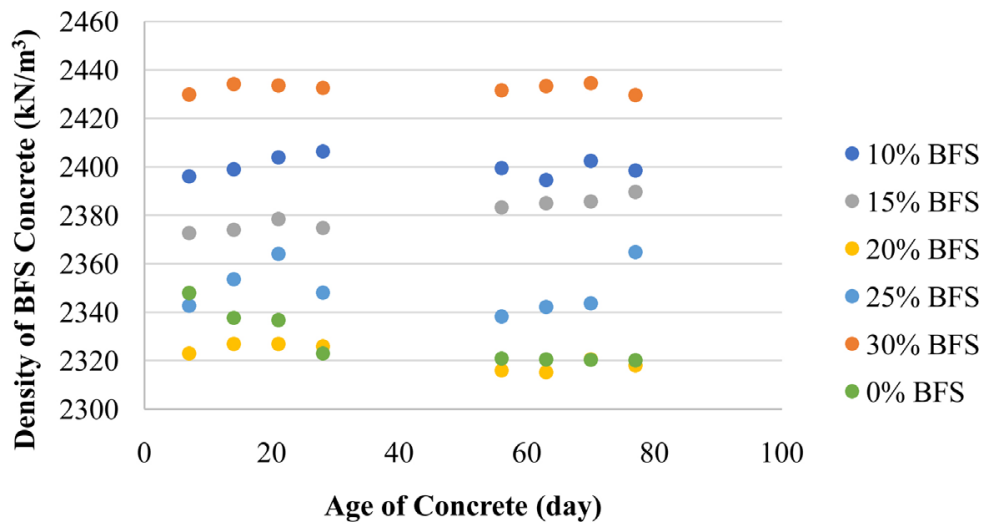

Figure 6. Density of concrete using BFS in ratios with time.

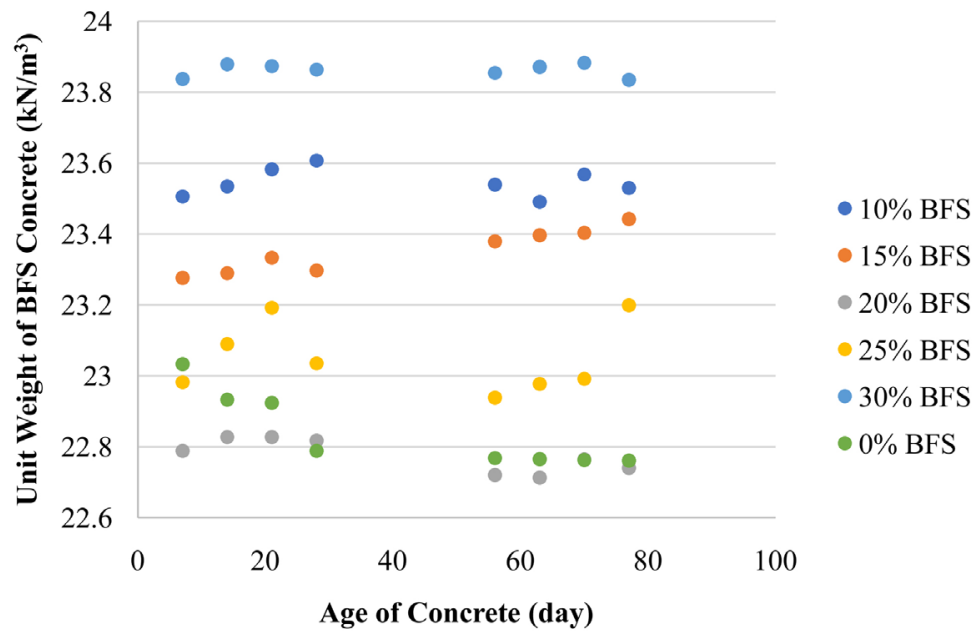

Figure 7. The unit weight of concrete using BFS with time.

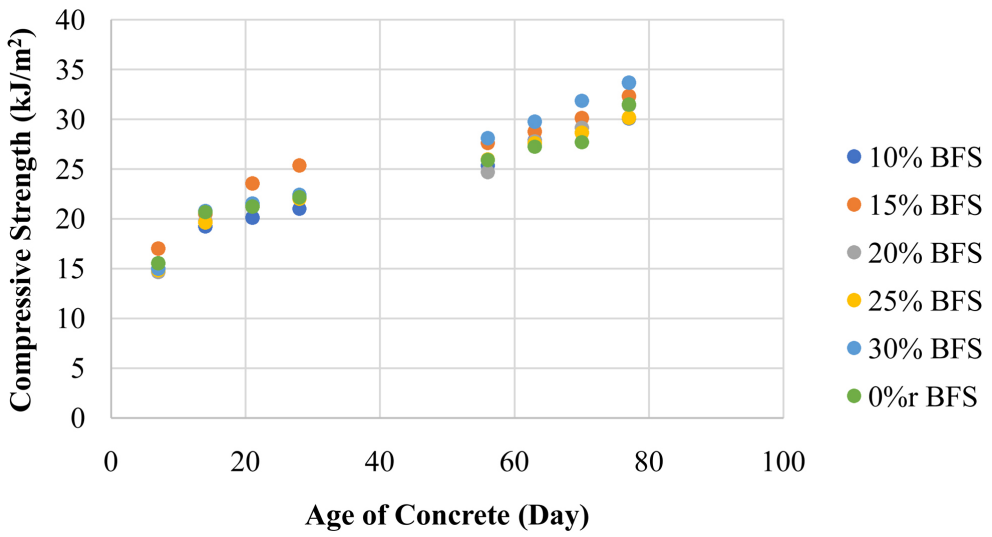

Figure 8. Compressive strength of concrete $\left(\mathrm{kN} / \mathrm{m}^{2}\right)$ using BFS.

\section{Discussion and Conclusions}

The use of BFS has many of the benefits for the concrete mix and its properties. Can BFS in the mix be increased to more than $30 \%$ ? This will be studied in a later stage of the present research. Harmful effects of the use of BFS were not 


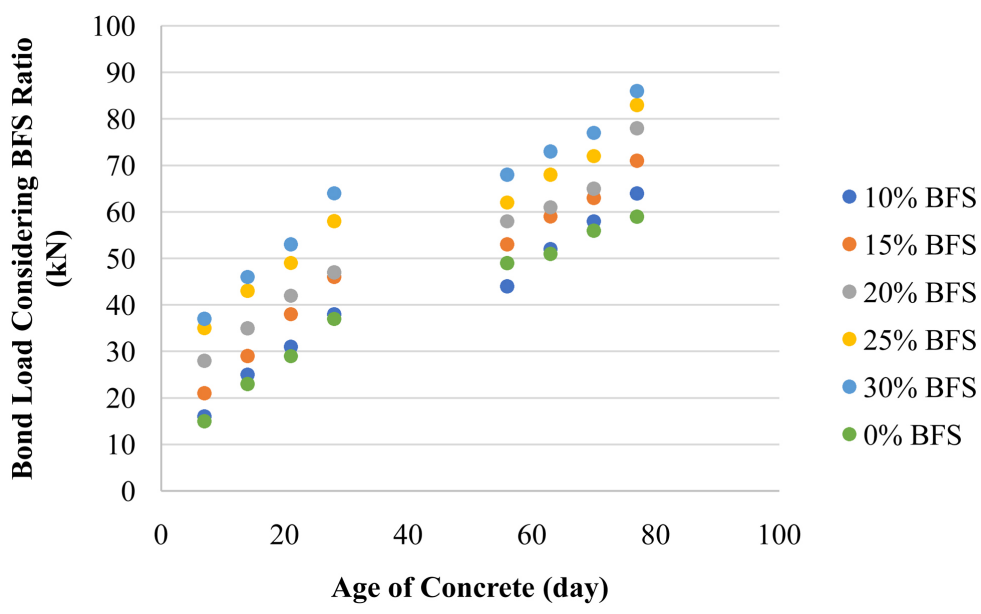

Figure 9. Bond load of concrete mix using BFS.

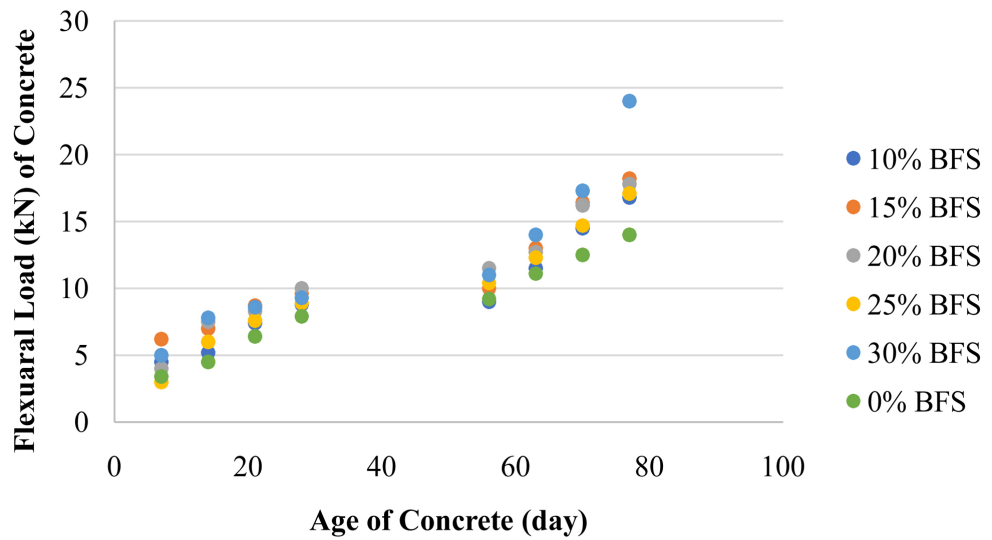

Figure 10. Flexural load $(\mathrm{kN})$ of concrete using BFS.

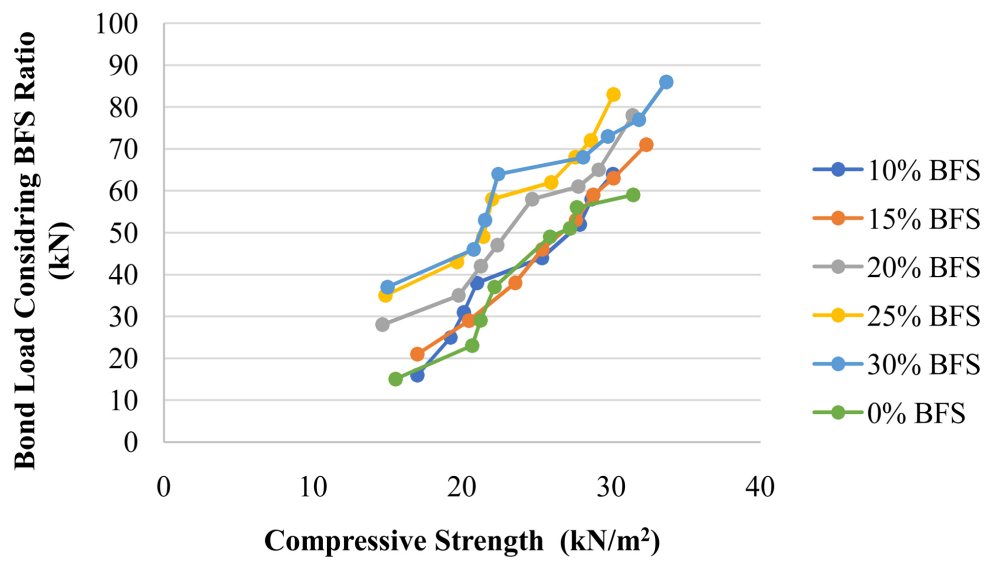

Figure 11. Bond load versus compressive strength for BFS concrete.

noticed neither on fresh mix nor on concrete samples during the period of manufacturing of concrete mixing, curing, and testing of samples that lasted for more than two months. Further research will be an opportunity to test the effects of using BFS in concrete mixes in the long run. 


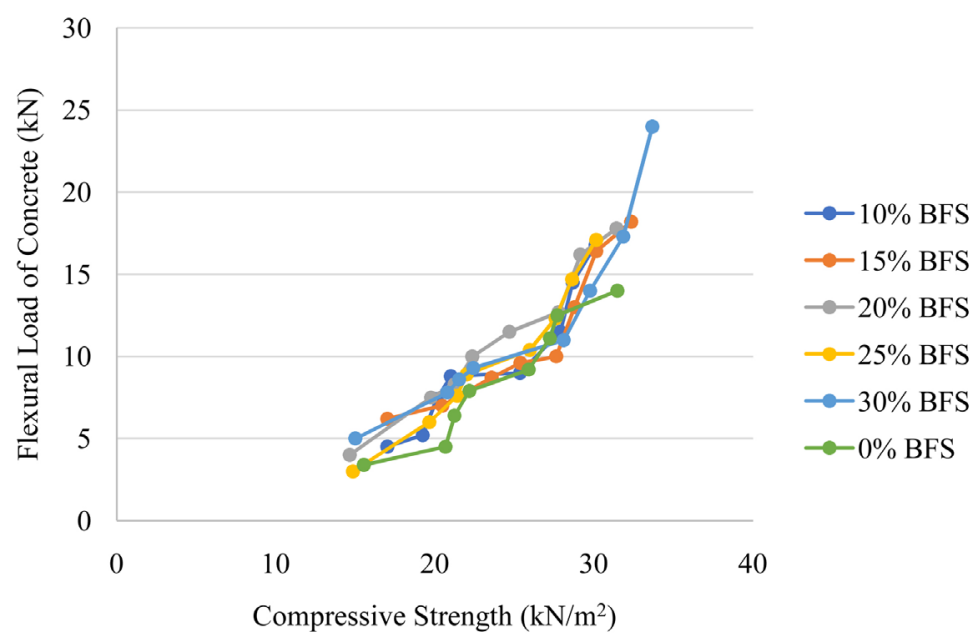

Figure 12. Flexural load of concrete versus compressive strength for BFS.

By conducting the current research, the following points are concluded:

- The use of $30 \%$ BFS mix can maintain the workability of concrete mix by flow table of $28 \mathrm{~cm}$.

- Slump value using BFS of $30 \%$ can be fixed at $6 \mathrm{~cm}$.

- Compaction factor of $98.5 \%$ is relevant to $25 \% \mathrm{BFS}$, and this is close to that of 0 -BFS concrete mix (with compaction factor of $99 \%$ ).

- VEBE-time is decreased by using the BFS (about 4 seconds at $30 \%$ of BFS in the concrete mix). So, the concrete mix becomes more workable by the addition of BFS.

- The compacted density of concrete mix using BFS at $30 \%$ is $2180 \mathrm{~kg} / \mathrm{m}^{3}$, and it is expected to increase by the increasing BFS ratio. The maximum density of non compacted concrete mix is $2050 \mathrm{~kg} / \mathrm{m}^{3}$.

- The density of 0-BFS hard concrete increased from $2330 \mathrm{~kg} / \mathrm{m}^{3}$ to $2430 \mathrm{~kg} / \mathrm{m}^{3}$ (for the $30 \%$ of BFS concrete).

- The unit weight of concrete of $0-B F S$ is $22.85 \mathrm{kN} / \mathrm{m}^{3}$, and for the $30 \%$ BFS is $23.9 \mathrm{kN} / \mathrm{m}^{3}$. So, the use of BFS will increase the unit weight of concrete.

- The compressive strength increased from $15 \mathrm{MPa}$ at $1^{\text {st }}$ week to $28 \mathrm{MPa}$ at 28 days to $34 \mathrm{MPa}$ at 84 days using the BFS in concrete mix.

- Bond load increased from $38 \mathrm{kN}$ at ${ }^{\text {st }}$ week to $88 \mathrm{kN}$ at 84 days (especially for the $30 \%$ BFS in concrete mix).

- Flexural load increased from $6 \mathrm{kN}$ at $1^{\text {st }}$ week to $24 \mathrm{kN}$ at 84 days (especially for $30 \%$ BFS concrete mix).

- Bond load and flexural strength can be derived from compressive strength data. The bond and flexure loads are highly related to the compressive strength of concrete and slag content.

Current research is a trial for the improvement of the properties of fresh mixes (during mixing, handling, and pouring) and hardened concrete (as the strength parameters will develop). Current research concentrated on compressive strength of concrete cubes. It is highly recommended to repeat the work including other 
tests (flexural, shear) and structural members (columns, beams, walls). Further research will be conducted to figure out the effect of BFS on the strength parameters of these elements.

\section{Conflicts of Interest}

The authors declare no conflicts of interest regarding the publication of this paper.

\section{References}

[1] Lee, H.-S., Wang, X.-Y., Zhang, L.-N. and Koh, K.-T. (2015) Analysis of the Optimum Usage of Slag for the Compressive Strength of Concrete. Materials, 8, 1213-1229. https://doi.org/10.3390/ma8031213

[2] Shariq, M., Prasad, J. and Masood, A. (2010) Effect of GGBFS on Time Dependent Compressive Strength of Concrete. Construction and Building Materials, 24, 1469-1478. https://doi.org/10.1016/j.conbuildmat.2010.01.007

[3] Metha, P.K. and Paulo, J.M. (2006) Concrete, Microstructure, Properties and Materials. McGraw-Hill, New York, 281-317.

[4] Beushausen, H., Alexander, M. and Ballim, Y. (2012) Early-Age Properties, Strength Development and Heat of Hydration of Concrete Containing Various South African Slags at Different Replacement Ratios. Construction and Building Materials, 29, 533-540. https://doi.org/10.1016/j.conbuildmat.2011.06.018

[5] Papadakis, V.G., Antiohos, S. and Tsimas, S. (2002) Supplementary Cementing Materials in Concrete Part II: A Fundamental Estimation of the Efficiency Factor. Cement and Concrete Research, 32, 1533-1538. https://doi.org/10.1016/S0008-8846(02)00829-3

[6] Sotiris, D., Maria, P.E. and Papadakis, V.G. (2014) Computer-Aided Modeling of Concrete Service Life. Cement and Concrete Composites, 47, 9-18. https://doi.org/10.1016/j.cemconcomp.2013.11.004

[7] Maekawa, K., Ishida, T. and Kishi, T. (2009) Multi-Scale Modeling of Structural Concrete. Taylor \& Francis, London, New York, 46-106.

[8] Iyoda, T., Inokuchi, K. and Uomoto, T. (2011) Effect of Slag Hydration of Blast Furnace Slag Cement in Different Curing Conditions. Proceedings of the 13 th International Congress on the Chemistry of Cement, Madrid, 3-8 July 2011, 257-265.

[9] Mohit, S.A., Haider, I., Awal, M.A. and Azam, M.A. (2015) Effect of Ground Granulated Blast Furnace Slag (GGBFS) on the Compressive Strength of Blended Cement Concrete. International Conference on Recent Innovation in Civil Engineering for Sustainable Development, Toronto, 2009, 1-22.

[10] British Standards, BS 1881: Part 103: 1983. Testing Concrete, Part 103. Method for Determination of Compacting Factor.

[11] ASTM International (2003) ASTM-C143. Standard Test Method for Slump of Hydraulic-Cement Concrete. West Conshohocken, 1-4.

[12] BS EN 12350-5, Testing Fresh Concrete. Flow Table Test.

[13] BS EN 12350-3:2009 Testing Fresh Concrete-Part 3: Vebe Test.

[14] BS 1881: Part 108: 1983. Method for Making Test Cubes from Fresh Concrete.

[15] BS 1881: Part 107: 1983. Method for Determination of Density of Compacted Concrete. 
[16] ASTM C138/C138M-17a, Standard Test Method for Density (Unit Weight), Yield, and Air Content (Gravimetric) of Concrete.

[17] Br. Stand. Inst. BSI (2002) BS-EN12390-3. Testing Hardened Concrete-Part 3: Compressive Strength of Test Specimens. 1-18.

[18] ASTM C1583. Tensile and Bond Stresses of Concrete Using Pullout.

[19] BS EN 12390-5:2009 Testing Hardened Concrete. Flexural Strength of Test Specimens. 